RECEIVED

NOV $\cap 82000$

$\mathrm{US}^{-}$

\title{
Annual Radiological Environmental Monitoring Program Report for the Three Mile Island, Unit 2, Independent Spent Fuel Storage Installation
}

G. G. Hall

Published February 2000

Idaho National Engineering and Environmental Laboratory Idaho Falls, Idaho 83415

Prepared for the

U.S. Department of Energy Assistant Secretary for Environmental Management Under DOE Idaho Operations Office Contract DE-AC07-99ID13727 


\section{DISCLAIMER}

This report was prepared as an account of work sponsored by an agency of the United States Government. Neither the United States Government nor any agency thereof, nor any of their employees, make any warranty, express or implied, or assumes any legal liability or responsibility for the accuracy, completeness, or usefulness of any information, apparatus, product, or process disclosed, or represents that its use would not infringe privately owned rights. Reference herein to any specific commercial product, process, or service by trade name, trademark, manufacturer, or otherwise does not necessarily constitute or imply its endorsement, recommendation, or favoring by the United States Government or any agency thereof. The views and opinions of authors expressed herein do not necessarily state or reflect those of the United States Government or any agency thereof. 


\section{DISCLAIMER}

Portions of this document may be illegible in electronic image products. Images are produced from the best available original document. 


\begin{abstract}
This report presents the results of the 1999 Radiological Environmental Monitoring Program conducted in accordance with 10 CFR 72.44 for the Three Mile Island, Unit 2, Independent Spent Fuel Storage Installation. A description of the facility and the monitoring program is provided. The results of monitoring the two predominant radiation exposure pathways, potential airborne radioactivity releases and direct radiation exposure, indicate facility operation has not contributed to any increase in the estimated maximum potential dose commitment to the general public.
\end{abstract}




\section{SUMMARY}

The purpose of this report is to present the results of the Radiological Environmental Monitoring Program (REMP) conducted during 1999 for the Three Mile Island, Unit 2 (TMI-2), Independent Spent Fuel Storage Installation (ISFSI). The first shipment of TMI-2 core debris was received and stored at the ISFSI on March 31, 1999. The next shipment is not scheduled for receipt until May 2000.

The REMP was implemented from March through December 1999. Results of the loose surface radioactive contamination surveys indicated no increase in either gross beta or CS-137 radioactivity. The results of the airborne radioactivity sampling did not indicate a release of airbome particulate radioactivity from the loaded Horizontal Storage Module (HSM). The results of the thermoluminescent dosimetry network did not indicate an increase in radiation levels above ambient background attributed to the facility operation.

The monitoring program results support the conclusion reached in the Final Environmental Impact Statement that operation of the facility would not result in a significant dose commitment to the Maximum Exposed Individual. 


\section{CONTENTS}

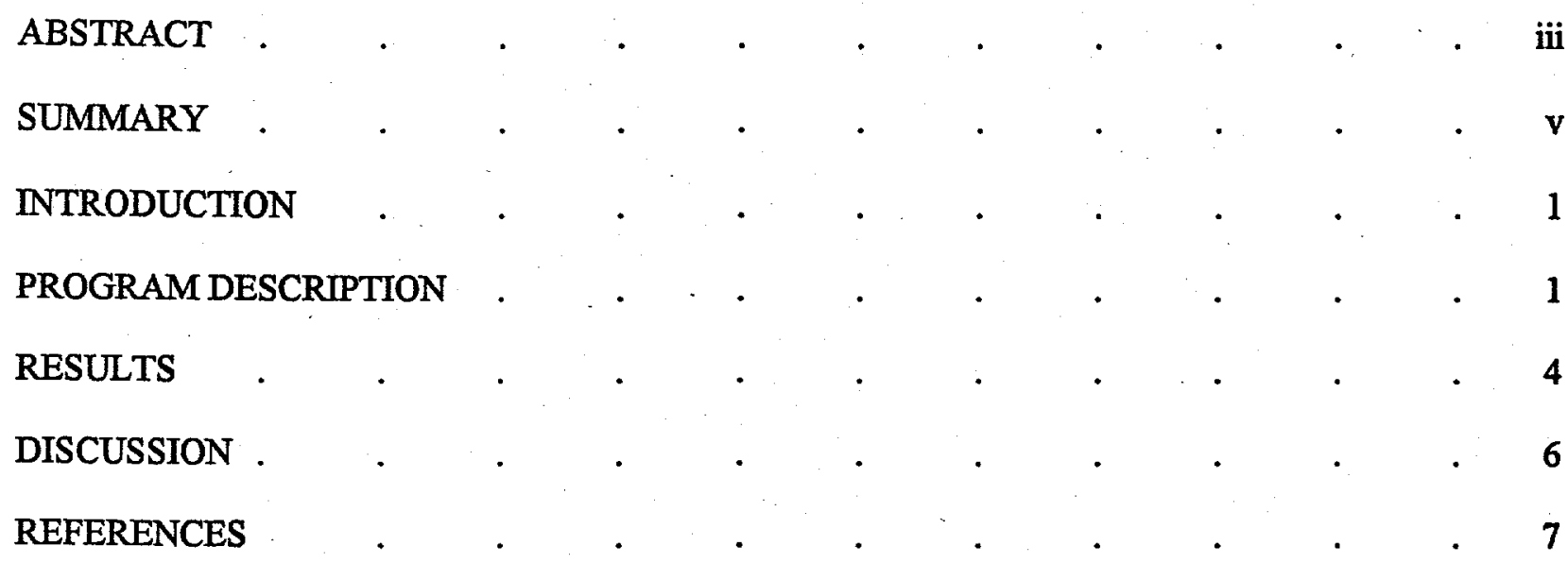

FIGURES

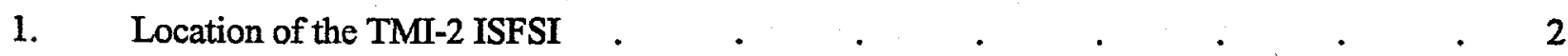

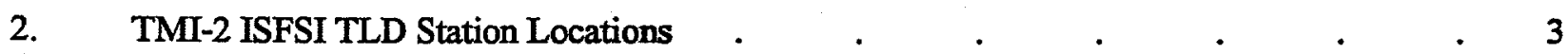

\section{TABLES}

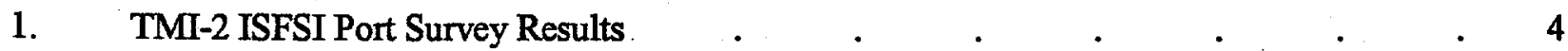

2. TMI-2 ISFSI Port Survey Gamma Isotopic Results $\quad$. $\quad$. $\quad$. $\quad$. $\quad$. 4

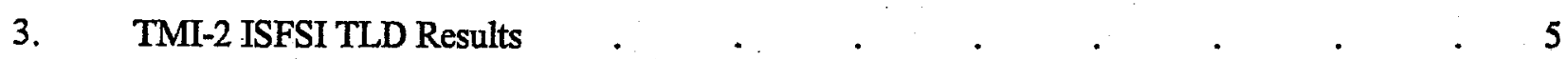

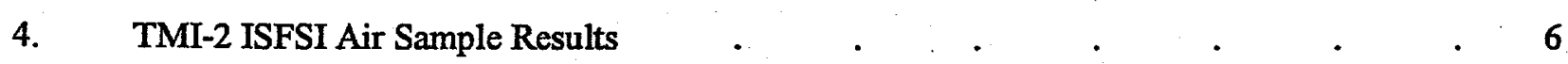

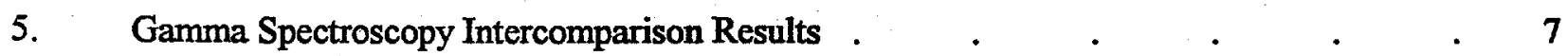




\section{Annual Radiological Environmental Monitoring Program Report for the Three Mile Island, Unit 2, Independent Spent Fuel Storage Installation}

\section{INTRODUCTION}

The Three Mile Island, Unit 2, Independent Spent Fuel Storage Installation (TMI-2 ISFSI) is a spent fuel dry storage facility designed for interim storage of the TMI-2 core debris. The TMI-2 ISFSI, located within the Idaho Nuclear Technology and Engineering Center (INTEC) at the Idaho National Engineering and Environmental Laboratory (INEEL) as shown in Figure 1, is operated by Bechtel BWXT Idaho, LLC for the Department of Energy (DOE). The TMI-2 ISFSI was licensed on March 19, 1999 by the Nuclear Regulatory Commission (NRC) pursuant to 10 CFR 72 for authorization to receive, possess, store, and transfer spent fuel and fuel debris, resulting from the 1979 TMI-2 accident, for a twenty-year term. ${ }^{1,2}$

The TMI-2 ISFSI is a modified NUHOMS spent fuel storage system, designated NUHOMS-12T. Each of the thirty NUHOMS-12T modules within the facility provide for the horizontal dry storage of up to twelve TMI-2 stainless steel canisters inside a dry shielded canister (DSC) which is placed inside a concrete horizontal storage module (HSM). The NUHOMS-12T modification includes venting of the DSC through high efficiency particulate air (HEPA) grade filters during storage. The vent system allows for release of hydrogen gas, generated due to radiolysis, and monitoring and/or purging of the system during operation.

The TMI-2 core debris, which has been stored in stainless steel canisters in a fuel pool at the Test Area North (TAN) site within the INEEL, is in the process of being transferred to the TMI-2 ISFSI for interim storage. A Settlement Agreement entered into by the State of Idaho, the Department of Energy, and the Department of the Navy in October 1995 established a schedule for commencing core debris transfers by March 31, 1999, and completing such transfers by June $1,2001{ }^{3}$ The first core debris transfer was completed on March 31, 1999. No further transfers are scheduled to occur again until May 2000.

A Radiological Environmental Monitoring Program (REMP) has been developed for the TMI-2 ISFSI and implemented in accordance with 10 CFR 72.44. This report presents the REMP results for the first nine months of the TMI-2 ISFSI operation.

\section{PROGRAM DESCRIPTION}

The REMP is designed to monitor the two predominant radiation exposure pathways inherent with the facility design: potential airborne radioactivity releases and direct radiation. The airborne radioactivity release pathway is monitored using a combination of loose surface radioactive contamination surveys and periodic airborne radioactivity sampling. The direct radiation exposure pathway is monitored using thermoluminescent dosimetry (TLD) located along the outer perimeter fence of the TMI-2 ISFSI. 


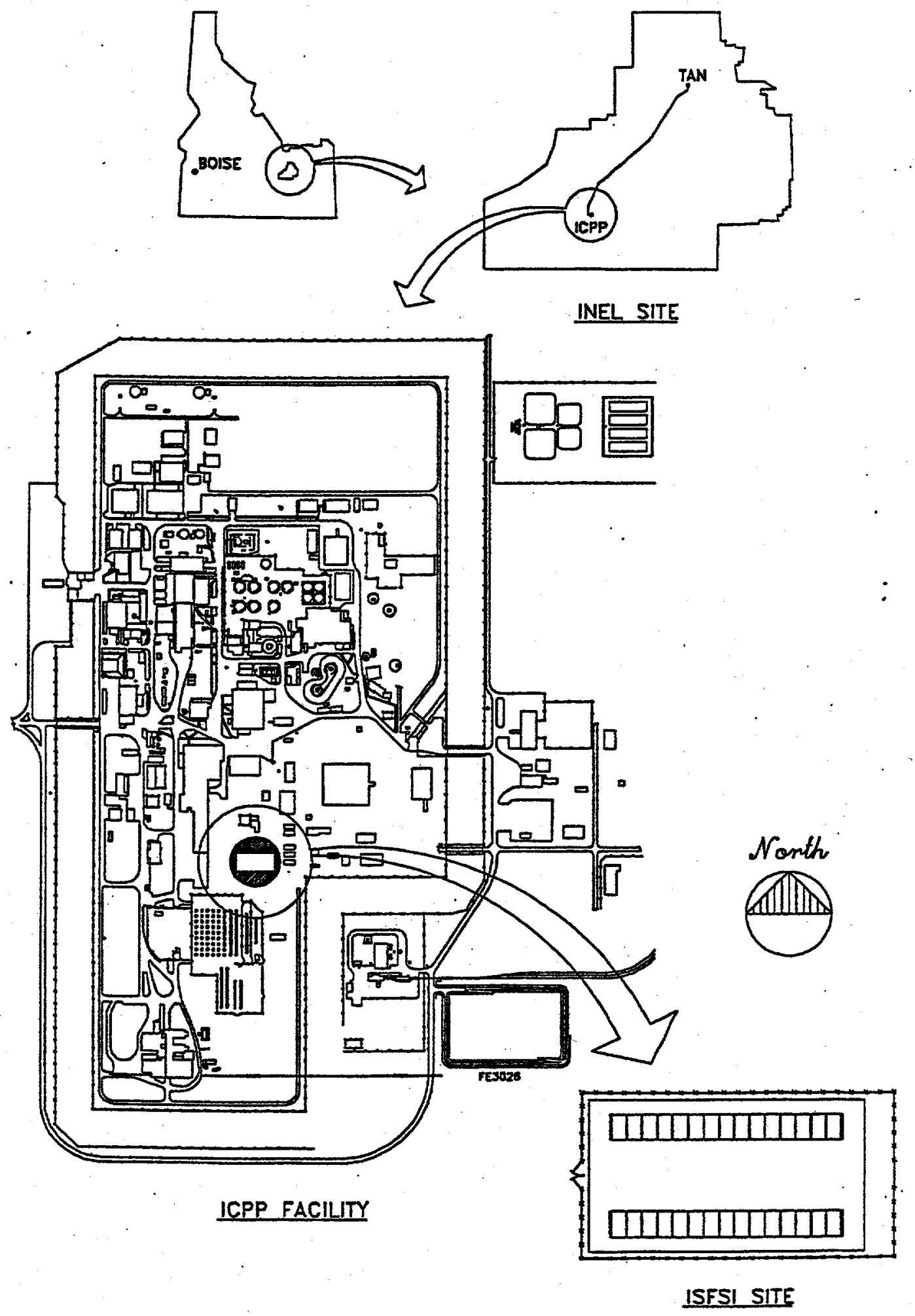

Figure 1. Location of the TMI-2 ISFSI. 
Loose surface radioactive contamination surveys are performed at the vent and purge ports of each DSC as well as the drain port of each loaded HSM. The survey frequency is monthly during the first year, quarterly during the second through fifth years, and annually thereafter. The survey frequency for each DSC and loaded HSM begins after DSC insertion into the HSM. The frequency coincides with the radiation monitoring surveillance schedule required by the TMI-2 ISFSI Technical Specifications. ${ }^{4}$ Sample media is analyzed for gross beta radioactivity. Depending on the amount of gross beta radioactivity detected, gamma isotopic analysis is either performed for each sample or for an annual sample composite. The presence of Cs-137 is determined and quantified during the gamma isotopic analysis with a required Lower Limit of Detection (LLD) no greater than $5 \mathrm{nCi}$.

Twenty-two TLD stations are located and maintained along the outer perimeter fence of the TMI2 ISFSI. Four additional TLD stations are maintained outside occupied buildings (CPP-665 and CPP666 ) within 100 meters of the TMI-2 ISFSI. The TLD station locations are noted in Figure 2. Dosimetry is changed out on a monthly frequency. The minimum detectable dose demonstrated is no greater than 10 mrem.

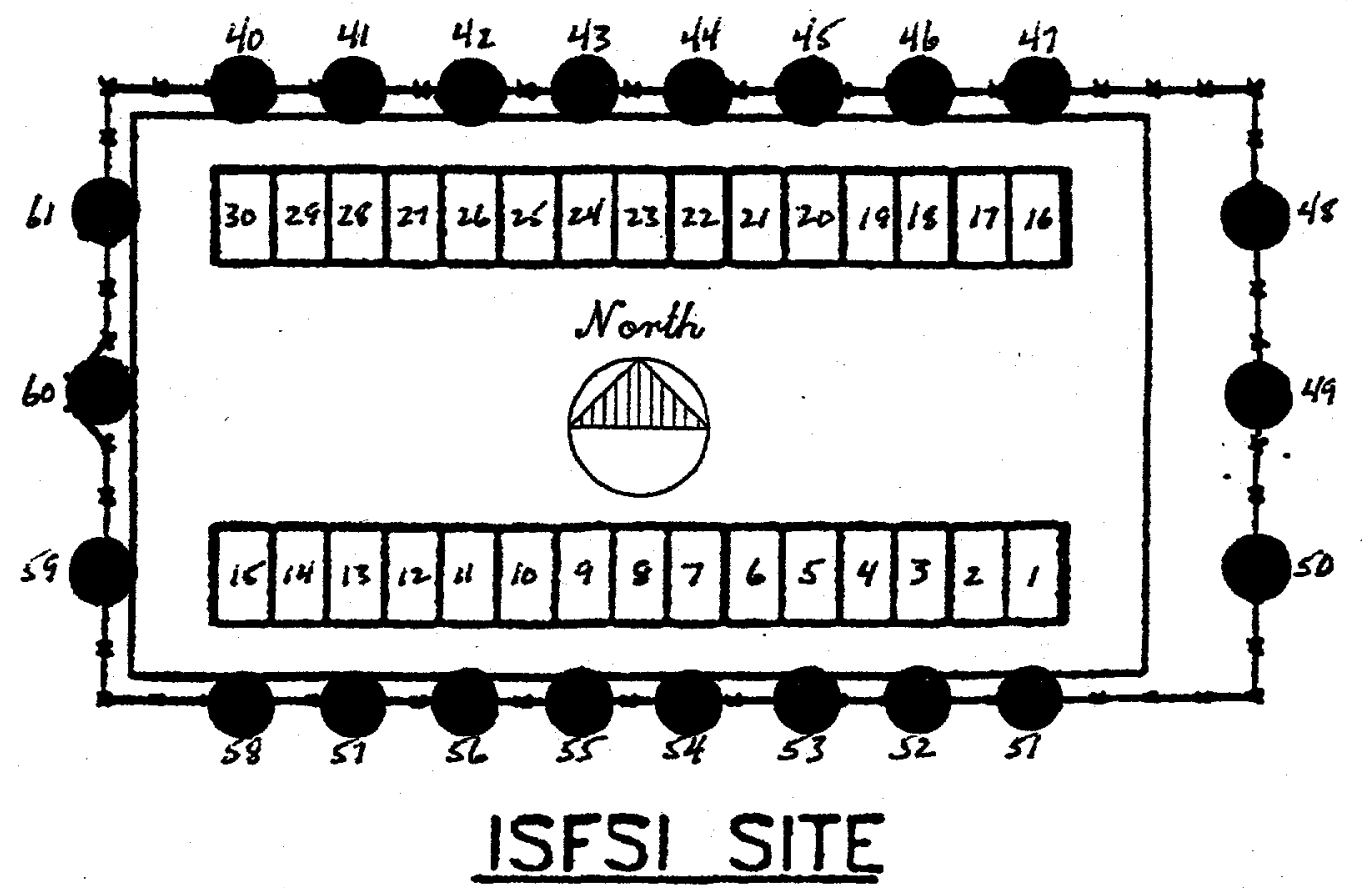

Figure 2. TMI-2 ISFSI TLD Station Locations.

A low-volume air sampler is used to collect a minimum of $1,000 \mathrm{ft}^{3}$ of air particulate during a twenty-four hour period either during each HSM loading or monthly during periods when no HSM loading operations are occurring. The air sampler is located inside the inner perimeter fence of the TMI-2 ISFSI in the most predominant wind direction from either the HSM being loaded or the center of the facility. Each air particulate sample is analyzed for gross beta radioactivity with an LLD no greater than $5 \mathrm{fCi} / \mathrm{m}^{3}$. Depending on the amount of gross beta radioactivity detected, gamma isotopic analysis is either performed for each air particulate sample or for an annual sample composite. The presence of Cs-137 is determined and quantified during the gamma isotopic analysis with a required Lower Limit of Detection (LLD) no greater than $8 \mathrm{fCi} / \mathrm{m}^{3}$. 


\section{RESULTS}

The first and only shipment of TMI-2 core debris during 1999 was received and loaded into HSM No. 16 on March 31, 1999. The highest individual occupational exposure received during the transfer at the TMI-2 ISFSI was 0 mrem. The collective occupational radiation exposure received during the transfer at the TMI-2 ISFSI was 0 person-rem. The contact radiation levels measured on the front door, rear panel door, filter housings, and end shield wall within the first 24 hours following the HSM loading were all less than or equal to $0.2 \mathrm{mrem} / \mathrm{h}$. Radiation levels measured during monthly DSC hydrogen gas sampling operations remained less than or equal to $0.2 \mathrm{mrem} / \mathrm{h}$.

Loose surface contamination survey results for the purge, vent, and drain ports on HSM No. 16 are summarized in Table 1. All analytical gross beta results were less than the Minimum Detectable Activity (MDA) calculated in accordance with NUREG-1507. The pre-operational baseline survey was performed March 25, 1999 on HSM No's. 14 and 29.

Table 1. TMI-2 ISFSI Port Survey Results.

Survey Date Gross Beta $\left(\mathrm{dpm} / 100 \mathrm{~cm}^{2}\right) \quad$ Gross Alpha $\left(\mathrm{dpm} / 100 \mathrm{~cm}^{2}\right)$

$\begin{array}{lll}\text { March 25 } & <26 \text { (baseline) } & <17 \text { (baseline) } \\ \text { March } 31 & <31 & <12 \\ \text { April 19 } & <22 & <17 \\ \text { May 19 } & <23 & <16 \\ \text { June 16 } & <22 & <12 \\ \text { July 21 } & <25 & <17 \\ \text { August 18 } & <25 & <16 \\ \text { September 16 } & <23 & <14 \\ \text { October 20 } & <24 & <17 \\ \text { November } 17 & <26 & <17 \\ \text { December 15 } & <21 & <17\end{array}$

The Cs-137 gamma isotopic results for the purge, vent, and drain port composite samples from HSM No. 16 are summarized in Table 2 in units of radioactivity per sample. The Cs-137 radioactivity detected in the vent port sample composite was less than the mean of the MDA's calculated for purge and drain port analyses performed the same day.

TLD results for the TMI-2 ISFSI are presented in Table 3 in units of mrem/d. Monthly standard deviations were generally 0.1 to $0.2 \mathrm{mrem} / \mathrm{d}$. Analysis of variance results indicated monthly variances were different than the pre-operational baseline variance measured in March 1999. T-test results indicated monthly mean TLD responses were significantly different than the pre-operational baseline mean every month; higher in April due to core debris transfer activity and lower during the remaining months due to implementation of a new environmental dosimeter and processing system. It was also noted that mean TLD location response for the six stations in the southwest corner of the TMI-2 ISFSI were generally the highest. This is attributed to direct radiation from spent fuel transfer activities that occurred in CPP-603, CPP-666, and CPP-749 during the monitoring period. The mean response of TLD's located in the two buildings within the 100 meter perimeter of the TMI-2 ISFSI were not significantly different than those at the perimeter fence. 
Table 2. TMI-2 ISFSI Port Survey Gamma Isotopic Results.

\begin{tabular}{ll}
\hline Sample Composite & Cs-137 Radioactivity \\
\hline Vent Port & $5.12 \mathrm{E}-3+1-6.6 \mathrm{E}-4 \mathrm{nCi}$ \\
Purge Port & $<4.141 \mathrm{E}-3 \mathrm{nCi}$ \\
Drain Port & $<8.012 \mathrm{E}-3 \mathrm{nCi}$ \\
\hline
\end{tabular}

Table 3. TMI-2 ISFSI TLD Results.

STN MAR APR MAY JUN JUL AUG SEP OCT NOV DEC Mean

$\begin{array}{llllllllllll}40 & 1.4 & 1.2 & 1.2 & 0.7 & 0.7 & 0.6 & 0.6 & 0.6 & 0.6 & 0.6 & 0.8 \\ 41 & 1.4 & 1.1 & 1.0 & 0.6 & 0.7 & 0.6 & 0.6 & 0.6 & 0.5 & 0.6 & 0.8 \\ 42 & 0.9 & 1.2 & 1.1 & 0.6 & 0.7 & 0.6 & 0.6 & 0.6 & 0.5 & 0.5 & 0.7 \\ 43 & 1.4 & 1.2 & 1.0 & 0.6 & 0.7 & 0.6 & 0.6 & 0.6 & 0.5 & 0.5 & 0.8 \\ 44 & 1.2 & 1.2 & 1.1 & 0.6 & 0.7 & 0.6 & 0.6 & 0.6 & 0.5 & 0.5 & 0.8 \\ 45 & 1.5 & 1.1 & 1.0 & 0.5 & 0.6 & 0.6 & 0.6 & 0.6 & 0.5 & 0.6 & 0.8 \\ 46 & 1.1 & 1.1 & 1.0 & 0.5 & 0.6 & 0.6 & 0.6 & 0.6 & 0.5 & 0.5 & 0.7 \\ 47 & 0.8 & 1.4 & 0.9 & 0.5 & 0.6 & 0.6 & 0.6 & 0.6 & 0.5 & 0.5 & 0.7 \\ 48 & 1.0 & 1.1 & 0.9 & 0.6 & 0.6 & 0.6 & 0.6 & 0.6 & 0.5 & 0.5 & 0.7 \\ 49 & 1.1 & 1.3 & 0.9 & 0.6 & 0.7 & 0.6 & 0.7 & 0.6 & 0.6 & 0.6 & 0.8 \\ 50 & 1.0 & 1.4 & 0.8 & 0.6 & 0.7 & 0.6 & 0.7 & 0.7 & 0.6 & 0.6 & 0.8 \\ 51 & 1.1 & 1.3 & 0.9 & 0.7 & 0.8 & 0.7 & 0.7 & 0.7 & 0.6 & 0.6 & 0.8 \\ 52 & 0.9 & 1.3 & 1.3 & 0.7 & 0.8 & 0.7 & 0.7 & 0.7 & 0.6 & 0.7 & 0.8 \\ 53 & 1.1 & 1.3 & 1.1 & 0.8 & 0.8 & 0.7 & 0.7 & 0.7 & 0.6 & 0.6 & 0.8 \\ 54 & 1.1 & 1.2 & 1.2 & 0.8 & 0.8 & 0.7 & 0.8 & 0.7 & 0.6 & 0.7 & 0.9 \\ 55 & 1.0 & 1.5 & 1.1 & 0.8 & 0.9 & 0.8 & 0.7 & 0.8 & 0.7 & 0.7 & 0.9 \\ 56 & 1.0 & 1.4 & 1.1 & 0.8 & 0.9 & 0.8 & 0.8 & 0.8 & 0.7 & 0.7 & 0.9 \\ 57 & 1.1 & 1.1 & 1.1 & 0.7 & 0.9 & 0.8 & 0.8 & 0.8 & 0.7 & 0.7 & 0.9 \\ 58 & 1.4 & 1.7 & 1.2 & 0.8 & 0.9 & 0.9 & 0.8 & 0.8 & 0.8 & 0.8 & 1.0 \\ 59 & 1.1 & 1.6 & 1.2 & 0.8 & 0.9 & 0.8 & 0.8 & 0.8 & 0.7 & 0.8 & 1.0 \\ 60 & 1.1 & 1.1 & 1.0 & 0.8 & 0.8 & 0.7 & 0.7 & 0.7 & 0.6 & 0.7 & 0.8 \\ 61 & 1.1 & 1.2 & 1.0 & 0.7 & 0.8 & 0.7 & 0.7 & 0.7 & 0.6 & 0.7 & 0.8\end{array}$

$\begin{array}{llllllllllll}\text { Mean } & 1.1 & 1.3 & 1.0 & 0.7 & 0.8 & 0.7 & 0.7 & 0.7 & 0.6 & 0.6\end{array}$

$\begin{array}{llllllllllll}62 & 0.9 & 0.9 & 0.8 & 0.5 & 0.5 & 0.5 & 0.5 & 0.5 & 0.4 & 0.5 & 0.6 \\ 63 & 0.8 & 1.1 & 1.1 & 0.5 & 0.6 & 0.5 & 0.5 & 0.5 & 0.4 & 0.6 & 0.7 \\ 64 & 0.9 & 1.2 & 0.9 & 0.5 & 0.6 & 0.6 & 0.6 & 0.5 & 0.5 & 0.5 & 0.7 \\ 65 & 1.0 & 1.3 & 1.0 & 0.6 & 0.7 & 0.6 & 0.6 & 0.6 & 0.6 & 0.7 & 0.8\end{array}$

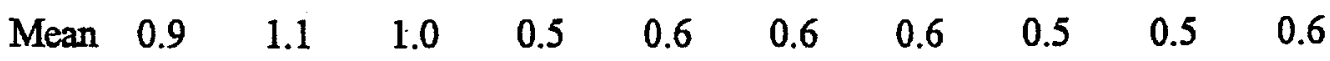


Air sampling results for the TMI-2 ISFSI are presented in Table 4. The required LLD of $5 \mathrm{fCi} / \mathrm{m}^{3}$ for gross beta radioactivity was not demonstrated. Radioanalytical count times used were based on MDA's required to detect $10 \%$ of the Derived Air Concentrations of either Sr-90 or Pu-239, not environmental Cs-137 concentrations. MDA's calculated after August 1999 were based on samples that were analyzed after a one-week holding period to allow for radon and thoron progeny decay. Adjustments to variables necesșary to achieve a lower LLD are being made for implementation during year 2000 radioanalyses. Consideration is also being given to changing the required LLD to $1 E-2 \mathrm{pCi} / \mathrm{m}^{3}$ to be consistent with USNRC guidance. ${ }^{6}$

Table 4. TMI-2 ISFSI Air Sample Results.

\section{Sample Date Gross Beta $\left(\mathrm{pCi} / \mathrm{m}^{3}\right)$}

$\begin{array}{ll}\text { March 30 } & <0.09 \\ \text { April 29 } & <0.14 \\ \text { May 19 } & <0.14 \\ \text { June 16 } & <0.13 \\ \text { July 21 } & <0.12 \\ \text { August 18 } & <0.13 \\ \text { September 16 } & <0.47 \\ \text { October 20 } & <0.46 \\ \text { November 22 } & <0.49 \\ \text { December 15 } & <0.45\end{array}$

Gamma spectroscopy results of the air sample composite indicated less than $5.0 \mathrm{E}-3 \mathrm{nCi} / \mathrm{sample}$ of Cs-137, or less than $6 \mathrm{E}-3 \mathrm{pCi} / \mathrm{m}^{3}$. The required LLD of $8 \mathrm{fCi} / \mathrm{m}^{3}$ was achieved as indicated by the calculated MDA of $6 \mathrm{fCi} / \mathrm{m}^{3}$.

\section{DISCUSSION}

With the one exception to achieving the required LLD for airborne gross beta radioactivity measurement, the TMI-2 ISFSI REMP was conducted in accordance with established procedures. There was no loss of monitoring data impacting estimation of the potential dose commitment to the general public. There were no changes in sampling locations during the monitoring period. There were no deviations from the established sampling schedule.

The loose surface radioactive contamination surveying and airborne radioactivity sampling results indicate there has been no measurable release of radioactive material from the DSC stored in HSM No. 16. Radioanalytical results are not significantly different from pre-operational results as well as those projected in the Final Environmental Impact Statement (EIS). ${ }^{7}$

The radiation dosimetry results indicate there has been no measurable increase in ambient background radiation levels outside the TMI-2 ISFSI perimeter fence attributed to storage of the TMI-2 core debris, however the results do indicate an influence from spent fuel storage and handling operations in adjacent facilities. A decrease in both the variance and mean of monthly dosimeter responses is indicative of the change to a different environmental dosimeter and dosimetry processing system used to 
support the REMP and reported by the processor in July $1999 .^{8}$ The absence of any significant increase in radiation levels outside the TMI-2 ISFSI perimeter fence is also supported by conclusions reached in the EIS.

Calibration and quality control of instrumentation used for gross beta analysis of surface contamination and airborne radioactivity sample media is maintained in accordance with procedures used by the INEEL Radiological Control Program. ${ }^{9}$ Radioactive sources used for instrumentation calibration and quality control are traceable to the National Institute of Standards and Technology (NIST). The radioanalytical program does not participate in either an intracomparison or intercomparison program.

The dosimetry processor routinely participates in an environmental dosimetry intercomparison program conducted by the DOE Environmental Measurements Laboratory (EML), but intercomparison studies were not conducted during 1999. The processor has registered to participate in the twelfth intercomparison scheduled to begin in early 2000.

The radioanalytical laboratory that provides gamma spectroscopy services for composite sample analysis does participate in regularly scheduled intercomparison program conducted by the EML. The last such intercomparison for the sample geometry used for composite samples of surface contamination survey and air sample media was conducted during the third quarter of 1999. The results are summarized in Table 5 for Sample Identification No. 9903AIIN. A description of the evaluation criteria can be found at the EML website (www.eml.doe.gov). The evaluation results for $\mathrm{Cs}-137$ identification indicate the INEEL is conservative in their reporting by $7 \%$.

Table 5. Gamma Spectroscopy Intercomparison Results.

\begin{tabular}{lllll}
\hline Radionuclide & INEEL Value (Error) & EML Value (Error) & INEEL/EML & Evaluation \\
\hline Co-60 & $5.14(0.1) \mathrm{Bq} /$ filter & $4.96(0.28) \mathrm{Bq} /$ filter & 1.036 & Acceptable \\
$\mathrm{Sb}-125$ & $4.32(0.5) \mathrm{Bq} /$ filter & $3.59(0.31) \mathrm{Bq} /$ filter & 1.203 & Warning \\
$\mathrm{Cs}-137$ & $6.48(0.9) \mathrm{Bq} /$ filter & $6.05(0.3) \mathrm{Bq} /$ filter & 1.071 & Acceptable \\
\hline
\end{tabular}

It can be concluded from the results of the TMI-2 ISFSI REMP that airborne radioactivity releases and direct radiation exposure from the facility during 1999 did not contribute to any increase in the estimate of maximum potential dose commitment to the general public, $2.7 \mathrm{E}-3 \mathrm{mrem} / \mathrm{y}$ effective dose equivalent to the Maximum Exposed Individual, reported in the EIS.

\section{REFERENCES}

1. Issuance of Materials License SNM-2508 for the Three Mile Island, Unit 2, Independent Spent Fuel Storage Installation (TAC No's L22283 and L22800), March 19, 1999, Docket No. 72-20.

2. 10 CFR 72, "Licensing Requirements for the Independent Storage of Spent Nuclear Fuel and High-Level Radioactive Waste", Code of Federal Regulations, Office of the Federal Register, August 1988. 
3. Settlement Agreement between the State of Idaho, Department of the Navy, and the Department of Energy, October 16, 1995.

4. Technical Specifications and Bases for the INEEL TMI-2 Independent Spent Fuel Storage Installation, Current issue.

5. NUREG/CR-1507, "Minimum Detectable Concentrations with Typical Radiation Survey Instruments for Various Contaminants and Field Conditions", December 1997.

6. USNRC Regulatory Guide 4.8, "Environmental Technical Specifications for Nuclear Power Plants", December 1975.

7. NUREG-1626, "Final Environmental Impact Statement for the Construction and Operation of an Independent Spent Fuel Storage Installation to Store the Three Mile Island Unit 2 Spent Fuel at the Idaho National Engineering and Environmental Laboratory", Docket No. 72-20, March 1998.

8. P. E. Ruhter, New Environmental Dosimeter Response, letter PER-17-99, July 29, 1999.

9. INEEL, Radiological Control Manuals 15B and 15C, Current issues. 